Bangl. J. Vet. Med. (2010). 8(1): $41-50$

\title{
EPIDEMIOLOGY AND PATHOLOGY OF ECTOPARASITIC INFESTATIONS IN BLACK BENGAL GOATS IN GAIBANDHA AND MYMENSINGH DISTRICTS OF BANGLADESH
}

\author{
M. Sarkar, S. A. Rahman, B. K. Sarker ${ }^{1}$, Anisuzzaman, N. Begum and M. M. H. Mondal \\ Department of Parasitology, Faculty of Veterinary Science, Bangladesh Agricultural University, Mymensingh - \\ $2202,{ }^{1}$ Department of Pathology, Faculty of Veterinary Science, Bangladesh Agricultural University, \\ Mymensingh - 2202, Bangladesh
}

\begin{abstract}
Epidemiology and pathology of ectoparasitic infestations in Black Bengal goats were studied in different areas of Mymensingh and Gaibandha districts, Bangladesh from December, 2006 to November, 2007. A total of 125 Black Bengal goats were examined. Among them $91(72.8 \%)$ were infested with one or more species of ectoparasites. Six species of ectoparasites were identified, of which four species were arachnids, namely Heamaphysalis bispinosa (34.4\%), Boophilus microplus (27.2\%), Rhipicephalus sanguineus (7.2\%), and Psoroptes cuniculi (5.6\%) and two species belonged to the class Insecta namely Damalinia caprae (20.8\%) and Linognathus stenopsis (18.4\%). Overall mean parasitic burden was $2.36 \pm 1.49$ per square inch of affected area. The highest parasitic burden was recorded in case of L. stenopsis (3.93 \pm 2.219$)$, followed by

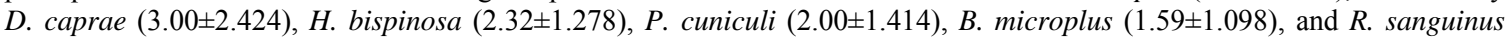
$(1.33 \pm 0.516)$. Significantly $(\mathrm{p}<0.01)$ higher prevalence of ectoparasites was recorded in the rainy season $(90 \%)$, followed by winter $(82.61 \%)$, and summer $(53.06 \%)$. The ectoparasitic infestation was higher in case of kids $(82 \%)$ and older goats $(79.55 \%)$ than that of young $(51.61 \%)$ goats. The female goats $(77.63 \%)$ were more susceptible than male $(65.31 \%)$ to ectoparasitic infestation. The prevalence of ectoparasites was higher in Mymensingh (87.5\%) than that of Gaibandha region $(57.38 \%)$. In the present study, pathological lesions produced by ectoparasites were also studied. In P. cuniculi infestation, alopecia, rough, dry and leathery skin was found. Microscopically, it was characterized by hyperkeratinization, ulceration, acanthosis and eosinophilic infiltration. In tick infestation, rough, reddened skin and loss of hair were observed. In lice infestation, the skin was red and slightly elevated. The ectoparasites produced pathological lesions on the skin which reduces the value and quality of skin.
\end{abstract}

Key words: Epidemiology, pathology, ectoparasitic infestation, black bengal goat

\section{INTRODUCTION}

There are about 34.5 million goats in Bangladesh (Anon, 2003). Next to Africa (41.3\%), the Indian subcontinent has the largest (31.4\%) goat population (Anon, 1979). The Black Bengal goat occupies the second position in livestock population and it plays an important role in the rural economy and export trades of Bangladesh. About $97.90 \%$ of goats are distributed in rural areas and $2.10 \%$ in urban areas (Anon, 1986). Most of these goats belong to indigenous Black Bengal breed. But goat rearing is hindered by various problems, among them parasitism is an important limiting factor in Bangladesh as the climatic condition of the country favors the development and survival of various parasites. Of the parasitic problems, ectoparasitic infestations are commonly seen in goats.

Common ectoparasites of animals are ticks, lice and mites (Nooruddin and Mondal, 1996; Nooruddin and Dey, 1989; Rahman and Mondal, 1985; Huq and Mollah, 1972; Kader and Huq, 1973). They are annoying pests because of their movement over the skin. The damage done by the ectoparasites cause considerable amount of blood loss, irritation and annoyance. As a result, feeding and digestion is hampered that may lead to retarded growth, loss of weight and reduced milk and meat production. The infested goats bite and rub the affected area so that the affected skin becomes abraded. Ultimately myiasis and other infections may occur which might lead to death of the animals (Soulsby, 1982). Ectoparasitic infestations reduce the quality and market value of valuable skin. Besides, ectoparasites transmit various types of deadly pathogens of animals (Soulsby, 1982).

Unfortunately, little attention was paid to the epidemiological factors influencing the prevalence of ectoparasitic infestation in Black Bengal goats and the pathological changes produced by the parasites in Bangladesh. Therefore, the present research work was planned to study the overall prevalence of ectoparasites and the effect of age, sex, seasons and geographic variations on ectoparasitism in Black Bengal goats along with the gross and histopathological changes produced by ectoparasitic infestations in Black Bengal goats. 


\section{Sarkar and other}

\section{MATERIALS AND METHODS}

Study area

One hundred and twenty five (125) goats were selected randomly from different areas of Gaibandha and Mymensingh districts, Bangladesh during the period of December 2006 to November 2007. Their ages ranged from 15 days to 3.5 years.

\section{Examination of goats}

For the collection of ectoparasites and detection of clinical manifestations (dandruff, thickening of skin, abnormal pigmentation, desquamation, ulceration and alopecia) relevant to ectoparasitic infestation, the selected goats were thoroughly investigated by close inspection, digital palpation and parting the hairs. Ectoparasites were counted in per square inches of areas.

\section{Collection, preservation and identification of ectoparasites}

Ticks and lice were collected from different parts of the body of the goats by hand picking and by using tools. When required, small camel hair brush dipped in ethanol was used for the collection of ticks and fine black comb was used for the collection of lice. The point of attachment was smeared with ethanol. Adequate precautions were taken to preserve the mouth parts and appendages of the ectoparasites during collection. To collect mites, skin scrapings from the affected areas were collected and the skin scrapings were examined by adding $10 \%$ potassium hydroxide (Hendrix and Robinson, 2006). Ticks and lice were preserved in $70 \%$ alcohol in clean, well-stopper glass vials. Permanent slides were prepared by following the procedures described by Cable (1957). Ectoparasites were identified according to the keys and descriptions given by Ferris (1951), Roberts (1952), Hoogstraal (1956) and Soulsby (1982).

\section{Study of pathological changes due to ectoparasitic infestations}

The goats were examined carefully to detect gross pathological changes, if any. Biopsy materials of the skin were collected from the affected part and fixed in $10 \%$ buffered neutral formalin solution for histopathological studies. The well-fixed tissues were processed and stained following the procedure of Luna (1968).

\section{Statistical analysis}

Statistical analyses were carried out by using Statistical Package for Social Sciences (SPSS). To determine the susceptibility of different groups of goats to ectoparasitic infestation, odds ratio was calculated according to the formula given by Sclesselman 1982.

\section{RESULTS}

Among 125 examined goats, 91 (72.8\%) (Table 2) were infested with one or more species of ectoparasites. A total of 6 species of ectoparasites were identified, of them 3 were ticks namely Haemaphysalis bispinosa (34.4 $\%$ ), Boophilus microplus (27.2\%), Rhipicephalus sanguineus (7.2\%), and one was mite, Psoroptes cuniculi (5.6\%) and 2 were lice such as Damalinia caprae (20.8\%) and Linognathus stenopsis (18.4\%) (Table 1, 2). Mean parasitic burden was almost equal in case of L. stenopsis (3.93 \pm 2.219$)$ and D. caprae (3.00 \pm 2.424$)$. Relatively low parasitic burden was found in case of $R$. sanguineus (1.33 \pm 0.516$)$ infestation.

Prevalence of ectoparasites was lower $(51.61 \%)$ in young animals ( $>6$ months to 1year) than that of kids $(\leq 6$ months), (82\%); and older animals ( $>1$ year), $(79.55 \%)$. Calculated odds ratio implied that kids were 4.27 times more susceptible to ectoparasitic infestation than young goats. But the older animals were 3.65 times more susceptible than young animals. Results also implies that kids and older animals are almost equally (odd ratio 1.17) susceptible to ectoparasitic infestation. $P$. cuniculi infestation was found only in kids (10\%) and young $(6.45 \%)$ goats but not in adults. B. microplus and $H$. bispinosa infestation found more in adult goats than kids and young ones (Table 3 ).

In this study, prevalence of ectoparasites was slightly higher in females, $(77.63 \%)$ than males, $(65.31 \%)$ resulted in 1.84 times more susceptibility of female to ectoparasitic infestations than males. In male goats, prevalence was higher in case of D. caprae (30.61\%), followed by L. stenopsis $(24.49 \%)$. In female goats, prevalence was higher in case of $H$. bispinosa (42.11\%) followed by B. microplus (34.21\%) (Table 4). 
Epidemiology and pathology of ectoparasitic infestations in Black Bengal goats

Table 1. Ectoparasites affecting Black Bengal goats in Bangladesh

\begin{tabular}{|c|c|c|c|}
\hline Name of parasites & Distribution on host & Gross lesions & $\begin{array}{c}\text { Histopathological } \\
\text { Lesions }\end{array}$ \\
\hline $\begin{array}{l}\text { Haemaphysalis bispinosa } \\
\text { Neumann, } 1897 \text { (Fig. 1) } \\
\text { Boophilus microplus } \\
\text { Canestrini, } 1887 \text { (Fig. 2) } \\
\text { Rhipicephalus sanguineus } \\
\text { Latreille, } 1806 \text { (Fig. 3) }\end{array}$ & $\begin{array}{l}\text { Ear, base of the horn, } \\
\text { neck, tail, near the } \\
\text { coronary band, } \\
\text { interdigital space. }\end{array}$ & $\begin{array}{l}\text { Rough and reddened skin, loss of hair, } \\
\text { slightly elevated and skin damage due } \\
\text { to rubbing. }\end{array}$ & $\begin{array}{c}\text { No significant changes } \\
\text { were observed. }\end{array}$ \\
\hline $\begin{array}{l}\text { Damalinia caprae } \\
\text { Gurlt, } 1843 \text { (Fig. 5) } \\
\text { Linognathus stenopsis } \\
\text { Burmeister, } 1838 \text { (Fig. 6) }\end{array}$ & $\begin{array}{l}\text { Ear, face, neck, hind } \\
\text { quarter, ventral } \\
\text { abdomen, hindlegs, } \\
\text { costal area. } \\
\text { Ear, neck, abdominal } \\
\text { region, hind quarter, } \\
\text { tail of goats. }\end{array}$ & $\begin{array}{l}\text { Dermatitis with rough, dry, and lathery } \\
\text { skin, alopecia, thickening of skin, in } \\
\text { some cases corrugation and presence } \\
\text { of dandruff was common. } \\
\text { Red and slightly elevated skin. }\end{array}$ & $\begin{array}{c}\text { Hyperkeratosis, } \\
\text { acanthosis, eosinophilic } \\
\text { infiltration and necrotic } \\
\text { lesions. } \\
\text { No significant changes } \\
\text { were observed. }\end{array}$ \\
\hline
\end{tabular}

Table 2. Overall prevalence and population density of ectoparasites in Black Bengal goats in Bangladesh

\begin{tabular}{|c|c|c|c|}
\hline \multirow[t]{2}{*}{ Name of parasites } & \multirow{2}{*}{$\begin{array}{l}\text { No. of animals affected (\%) } \\
\qquad \mathrm{N}=125\end{array}$} & \multicolumn{2}{|c|}{ Parasitic burden } \\
\hline & & Range & Mean \pm SD \\
\hline H. bispinosa & $43(34.4 \%)$ & $1-5$ & $2.32 \pm 1.278$ \\
\hline R. sanguineus & $9(7.2 \%)$ & $1-2$ & $1.33 \pm 0.516$ \\
\hline B. microplus & $34(27.2 \%)$ & $1-5$ & $1.59 \pm 1.098$ \\
\hline D. caprae & $26(20.8 \%)$ & $1-8$ & $3.00 \pm 2.424$ \\
\hline L. stenopsis & $23(18.4 \%)$ & $1-9$ & $3.93 \pm 2.219$ \\
\hline P. cuniculi & $7(5.6 \%)$ & $1-4$ & $2.00 \pm 1.414$ \\
\hline Total & ${ }^{*} 91(72.8 \%)$ & $1-9$ & $2.36 \pm 1.492$ \\
\hline
\end{tabular}

$\mathrm{N}=$ Total number of animals examined

Table 3. Effect of age on the prevalence of ectoparasites of goats in Bangladesh

\begin{tabular}{|c|c|c|c|c|c|}
\hline \multirow[t]{2}{*}{ Age of animals } & \multirow{2}{*}{$\begin{array}{c}\text { Name of parasites } \\
\text { recovered }\end{array}$} & \multirow{2}{*}{$\begin{array}{c}\text { No.of animals affected } \\
(\%) .\end{array}$} & \multicolumn{2}{|c|}{ Parasitic burden } & \multirow[t]{2}{*}{ Odds ratio } \\
\hline & & & Range & Mean \pm SD & \\
\hline Kids & H. bispinosa & $16(32 \%)$ & $1-5$ & $2.5 \pm 1.433$ & Kids vs \\
\hline ( $\leq 6$ months) & R. sanguineus & $4(8 \%)$ & $1-2$ & $1.33 \pm 0.577$ & Young \\
\hline \multirow[t]{5}{*}{$\mathrm{n}=50$} & B. microplus & $13(26 \%)$ & $1-5$ & $2.25 \pm 1.581$ & $=4.27$ \\
\hline & D. caprae & $11(22 \%)$ & $1-8$ & $4.00 \pm 3.00$ & \\
\hline & L. stenopsis & $10(20 \%)$ & $2-9$ & $4.71 \pm 2.289$ & \\
\hline & P. cuniculi & $5(10 \%)$ & $1-4$ & $2.33 \pm 1.528$ & \\
\hline & Sub total & ${ }^{*} 41(82 \%)$ & $1-9$ & $2.86 \pm 1.73$ & \\
\hline Young & H. bispinosa & $6(19.35 \%)$ & $1-5$ & $2.5 \pm 1.915$ & Older \\
\hline (>6 months -1 & R. sanguineus & $2(6.45 \%)$ & 2 & $2.00 \pm 0.00$ & vs Young \\
\hline year) & B. microplus & $3(9.67 \%)$ & 1 & $1.00 \pm 0.00$ & $=3.65$ \\
\hline \multirow[t]{4}{*}{$\mathrm{n}=31$} & D. caprae & $7(22.58 \%)$ & $1-6$ & $2.4 \pm 2.074$ & \\
\hline & L. stenopsis & $5(16.13 \%)$ & $1-6$ & $3.00 \pm 2.646$ & \\
\hline & P. cuniculi & $2(6.45 \%)$ & 2 & $2.00 \pm 0.00$ & \\
\hline & Sub total & $16(51.61 \%)$ & $1-6$ & $2.15 \pm 1.659$ & \\
\hline Older & H. bispinosa & $21(47.73 \%)$ & $1-4$ & $2.14 \pm 1.027$ & Kids vs \\
\hline (>1 year) & $R$. sanguineus & $3(6.82 \%)$ & $1-1$ & $1.00 \pm 0.00$ & Older \\
\hline \multirow[t]{4}{*}{$\mathrm{n}=44$} & B. microplus & $18(40.91 \%)$ & $1-2$ & $1.25 \pm 0.452$ & $=1.17$ \\
\hline & D. caprae & $8(18.18 \%)$ & $1-5$ & $2.2 \pm 1.643$ & \\
\hline & L. stenopsis & $8(18.18 \%)$ & $1-6$ & $3.4 \pm 1.949$ & \\
\hline & Sub total & *35 (79.55\%) & $1-6$ & $2.02 \pm 1.012$ & \\
\hline
\end{tabular}

$\mathrm{n}=$ Total animals examined

$\mathrm{SD}=$ Standard deviation 


\section{Sarkar and other}

Table 4. Effect of sex on the prevalence of ectoparasites of goats in Bangladesh

\begin{tabular}{|c|c|c|c|c|c|}
\hline \multirow[t]{2}{*}{ Parameters } & \multirow[t]{2}{*}{ Name of parasites } & \multirow{2}{*}{$\begin{array}{l}\text { No. of animals } \\
\text { affected }(\%)\end{array}$} & \multicolumn{2}{|c|}{ Parasitic burden } & \multirow[t]{2}{*}{ Odds ratio } \\
\hline & & & Range & Mean \pm SD & \\
\hline Male & H. bispinosa & $11(22.45 \%)$ & $1-5$ & $2.71 \pm 1.70$ & \multirow{14}{*}{$\begin{array}{c}\text { Female vs } \\
\text { Male } \\
=1.84\end{array}$} \\
\hline \multirow[t]{6}{*}{$\mathrm{N}=49$} & R. sanguineus & $3(6.12 \%)$ & 1 & $1.00 \pm 0.00$ & \\
\hline & B. microplus & $8(16.33 \%)$ & $1-4$ & $1.6 \pm 1.342$ & \\
\hline & D. caprae & $15(30.61 \%)$ & $1-8$ & $3.6 \pm 2.57$ & \\
\hline & L. stenopsis & $12(24.49 \%)$ & $1-9$ & $4.38 \pm 2.559$ & \\
\hline & P. cuniculi & $2(4.08 \%)$ & 2 & $2.00 \pm 0.00$ & \\
\hline & Sub total & ${ }^{*} 32(65.31 \%)$ & $1-9$ & $2.55 \pm 1.673$ & \\
\hline Female & H. bispinosa & $32(42.11 \%)$ & $1-4$ & $2.19 \pm 1.123$ & \\
\hline \multirow[t]{6}{*}{$\mathrm{N}=76$} & R. sanguineus & $6(7.89 \%)$ & $1-2$ & $1.5 \pm 0.577$ & \\
\hline & B. microplus & $26(34.21 \%)$ & $1-5$ & $1.59 \pm 1.064$ & \\
\hline & D. caprae & $11(14.47 \%)$ & $1-5$ & $2.14 \pm 1.68$ & \\
\hline & L. stenopsis & $11(14.47 \%)$ & $1-6$ & $3.43 \pm 1.813$ & \\
\hline & P. cuniculi & $5(6.58 \%)$ & $1-4$ & $2.33 \pm 1.528$ & \\
\hline & Sub total & *59 (77.63\%) & $1-6$ & $2.19 \pm 1.297$ & \\
\hline
\end{tabular}

$\mathrm{N}=$ Total animals examined

Prevalence of ectoparasites was the highest in rainy season $(90 \%)$ followed by winter $(82.61 \%)$ and summer $(53.06 \%)$ seasons (Figure 3). In this study, it was also revealed that goats were 7.96 times more susceptible to ectoparasitic infestations in the rainy season than that of summer season. But in winter season, goats were 4.20 times more vulnerable to ectoparasitic infestations than summer season. On the other hand, in the rainy season goats were 1.89 times more prone to ectoparasitic infestations than in winter season.

In Mymensingh district $87.5 \%$ goats were infested with ectoparasites whereas in Gaibandha district the infestation was 57.38\%. Goats reared in Mymensingh region were 5.2 times more vulnerable to ectoparasitic infestation than Gaibandha region. Surprisingly, no louse was detected in the goats of Mymensingh district and no tick was detected in the goats of Gaibandha district (Table 5).

\section{Pathological lesions produced by different external parasites}

$P$. cuniculi infestation

The mites were mostly found on the ear, face, hind quarter and abdomen. Affected skin was rough, dry and leathery with loss of hair (alopecia). In some cases, skin was thick with mild to moderate corrugation. Dandruff was common (Figure 7,8). Histopathological lesions were characterized by hyperkeratosis, eosinophilic infiltration, acanthosis and superficially by the loss of cornified layer associated with aggregation of necrotic cellular debris (Figure 11, 12) (Table 1).

\section{Tick infestation (H. bispinosa, $R$. sanguineus, B. microplus)}

Ticks were found mostly on the external ears on both sides. However, they were also detected on the base of horn, neck, tail and on the interdigital spaces at the level of coronary band. Skin of the affected areas became rough and reddened. Loss of hair (alopecia) was seen in the heavily infested area. The site of attachment was slightly elevated. Sloughing of skin was also observed as a result of rubbing (Figure 9, 10).

\section{Lice infestation (D. caprae, L. stenopsis)}

In lice infestation, the pathological changes were not so pronounced. The site of attachment of lice was red and slightly elevated (Table 1). In some cases, pinpoint hemorrhages were noticed. 
Epidemiology and pathology of ectoparasitic infestations in Black Bengal goats

Table 5. Prevalence of ectoparasites in Black Bengal goats in different seasons and geographical locations of Bangladesh

\begin{tabular}{|c|c|c|c|c|c|}
\hline \multirow[t]{2}{*}{ Seasons } & \multirow[t]{2}{*}{ Name of parasites } & \multirow{2}{*}{$\begin{array}{l}\text { No. of animals } \\
\text { affected (\%) }\end{array}$} & \multicolumn{2}{|c|}{ Parasitic burden } & \multirow[t]{2}{*}{ Odds ratio } \\
\hline & & & Range & Mean \pm SD & \\
\hline \multirow{7}{*}{$\begin{array}{l}\text { Rainy } \\
\mathrm{n}=30\end{array}$} & H. bispinosa & $8(26.67 \%)$ & $1-4$ & $1.6 \pm 1.342$ & Rainy \\
\hline & $R$. sanguineus & $3(10 \%)$ & $1-2$ & $1.5 \pm 0.707$ & vs \\
\hline & B. microplus & $6(20 \%)$ & $1-3$ & $1.75 \pm 0.957$ & Winter \\
\hline & D. caprae & $8(26.67 \%)$ & $1-5$ & $2.00 \pm 1.732$ & $=1.89$ \\
\hline & L. stenopsis & $9(30 \%)$ & $2-6$ & $4.17 \pm 1.835$ & \\
\hline & P. cuniculi & $5(16.67 \%)$ & $1-4$ & $2.33 \pm 1.528$ & \\
\hline & Sub total & ${ }^{*} 27(90 \%)$ & $1-6$ & $2.23 \pm 1.350$ & \\
\hline \multirow{5}{*}{$\begin{array}{c}\text { Winter } \\
\mathrm{n}=46\end{array}$} & H. bispinosa & $33(71.74 \%)$ & $1-5$ & $2.5 \pm 1.263$ & Winter \\
\hline & R. sanguineus & $4(8.69 \%)$ & $1-2$ & $1.33 \pm 0.577$ & vs Summer \\
\hline & B. microplus & $25(54.35 \%)$ & $1-4$ & $1.31 \pm 0.793$ & $=4.20$ \\
\hline & P. cuniculi & $2(4.35 \%)$ & 2 & $2.00 \pm 0.00$ & \\
\hline & Sub total & "38 (82.61\%) & $1-5$ & $1.79 \pm 0.878$ & \\
\hline \multirow{6}{*}{$\begin{array}{c}\text { Summer } \\
\mathrm{n}=49\end{array}$} & H. bispinosa & $2(4.08 \%)$ & 2 & $2.00 \pm 0.00$ & Rainy \\
\hline & $R$. sanguineus & $2(4.08 \%)$ & 1 & $1.00 \pm 0.00$ & vs Summer \\
\hline & B. microplus & $3(6.12 \%)$ & $2-5$ & $3.5 \pm 2.121$ & $=7.96$ \\
\hline & D. caprae & $18(36.73 \%)$ & $1-8$ & $3.42 \pm 2.609$ & \\
\hline & L. stenopsis & $14(28.57 \%)$ & $1-9$ & $3.78 \pm 2.539$ & \\
\hline & Sub total & ${ }^{*} 26(53.06 \%)$ & $1-9$ & $2.74 \pm 2.423$ & \\
\hline \multirow{5}{*}{$\begin{array}{c}\underset{\mathrm{h}}{\text { Mymensing }} \\
\mathrm{n}=64\end{array}$} & H. bispinosa & $43(67.19 \%)$ & $1-5$ & $2.32 \pm 1.278$ & \multirow{9}{*}{$\begin{array}{c}\text { Mymensingh vs } \\
\text { Gaibandha } \\
=5.2\end{array}$} \\
\hline & R. sanguineus & $9(14.06 \%)$ & $1-2$ & $1.33 \pm 0.516$ & \\
\hline & B. microplus & $34(53.13 \%)$ & $1-5$ & $1.59 \pm 1.098$ & \\
\hline & P. cuniculi & $5(7.81 \%)$ & $1-4$ & $2.33 \pm 1.528$ & \\
\hline & Sub total & $56(87.5 \%)$ & $1-5$ & $1.89 \pm 1.105$ & \\
\hline Gaibandha & D. caprae & $26(42.62 \%)$ & $1-8$ & $3.00 \pm 2.424$ & \\
\hline \multirow[t]{3}{*}{$\mathrm{n}=61$} & L. stenopsis & $23(37.70 \%)$ & $1-9$ & $3.93 \pm 2.219$ & \\
\hline & P. cuniculi & $2(3.28 \%)$ & 2 & $2.00 \pm 0.00$ & \\
\hline & Sub total & $35(57.38 \%)$ & $1-9$ & $2.98 \pm 2.321$ & \\
\hline
\end{tabular}

$\mathrm{n}=$ Total animals examined 


\section{Sarkar and other}
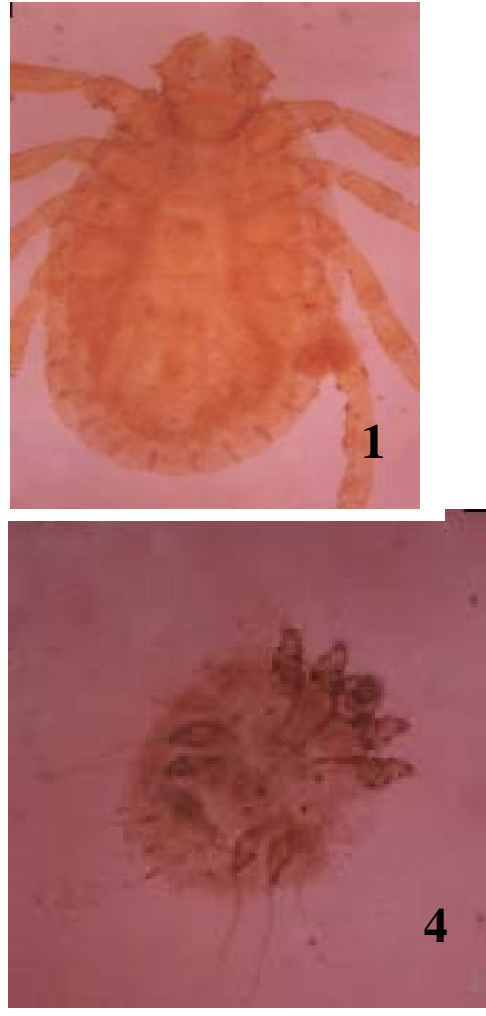

$$
2
$$
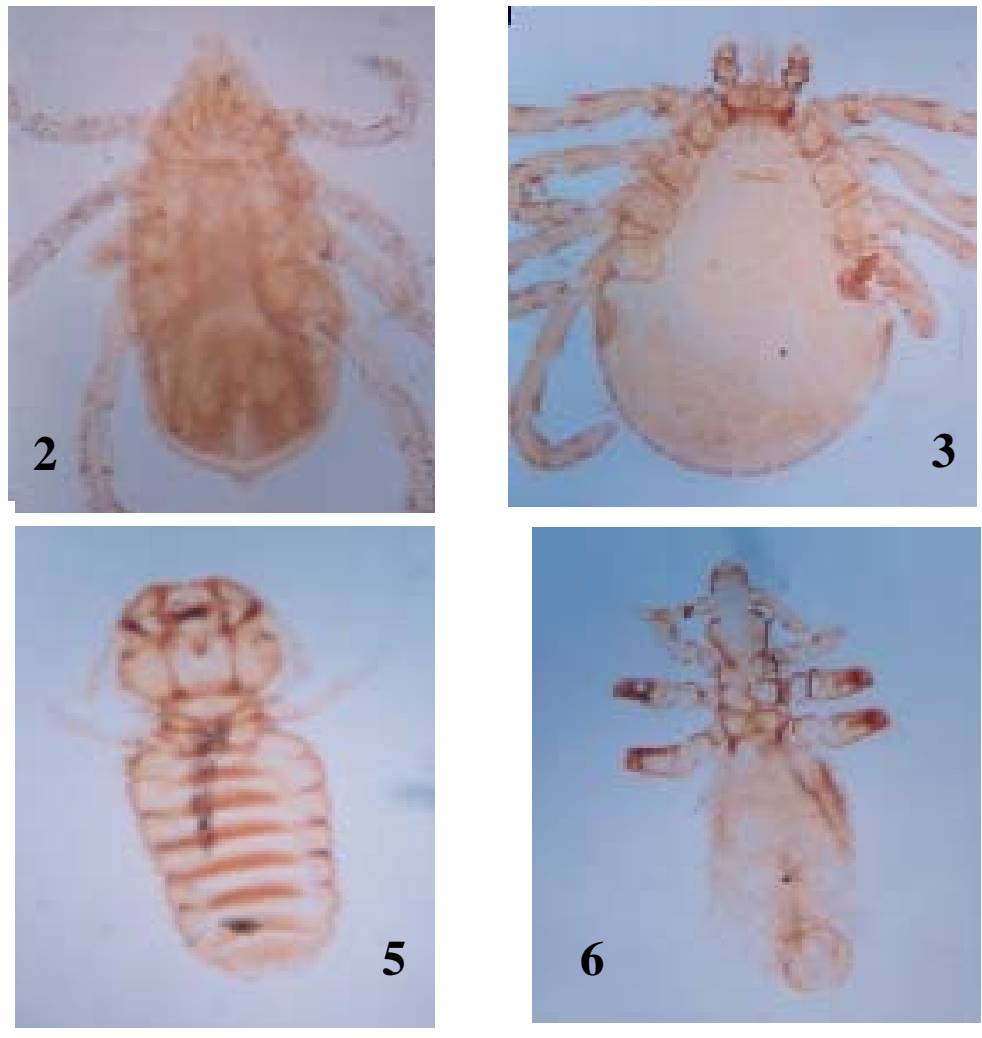

Figure 1. Haemaphysalis bispinosa, Figure 2. Boophilus microplus, Figure 3. Rhipicephalus sanguineus, Figure 4. Psoroptes cuniculi, Figure 5. Damalinia caprae and Figure 6. Linognathus stenopsis

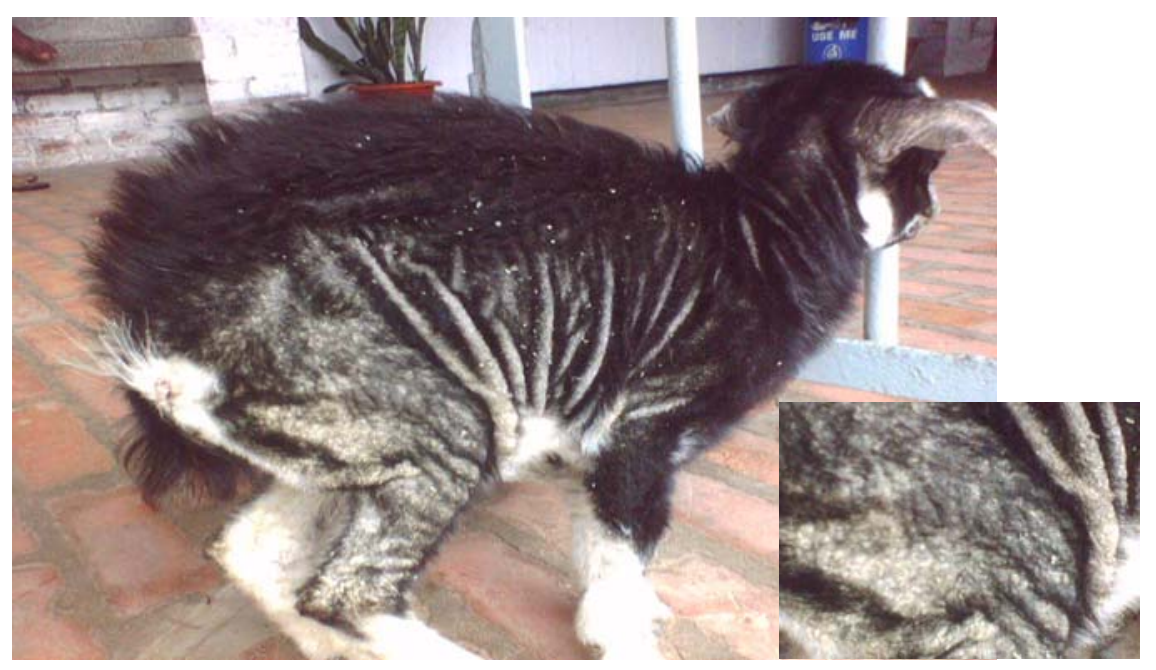

A

B

Figure 7(A). Severe infestation with $P$. cuniculi characterized by alopecia, dandruff, thickening and corrugation of skin, (B) higher magnification of the lesions of figure A 
Epidemiology and pathology of ectoparasitic infestations in Black Bengal goats

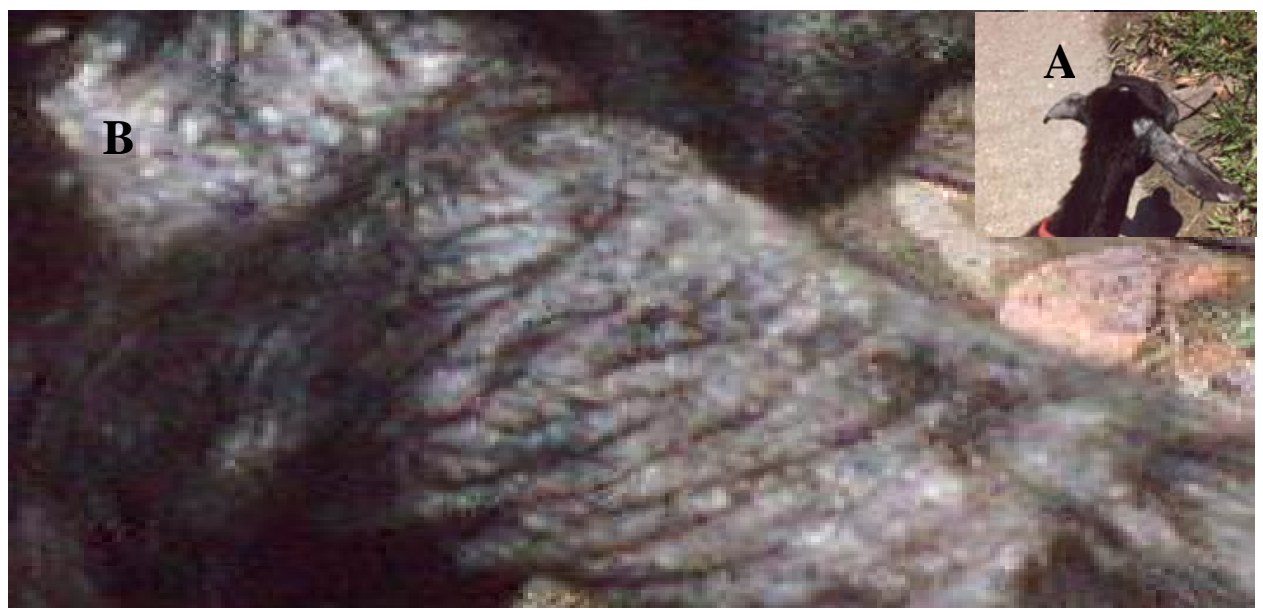

Figure 8(A). Ear of goat severely affected with $P$. cuniculi, (B) higher magnification of the lesions of figure $\mathrm{A}$.

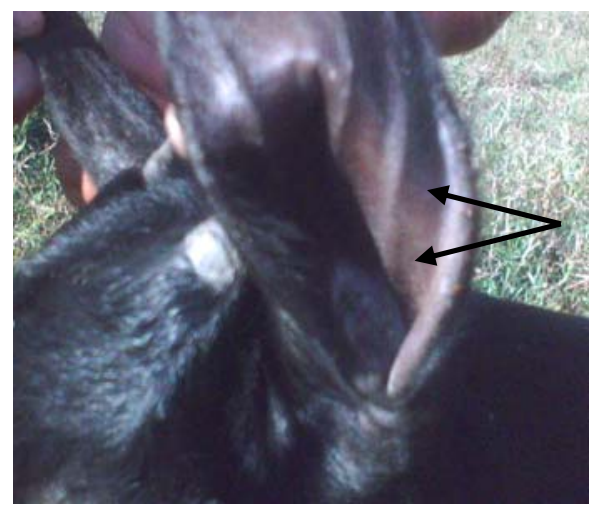

Figure 9. Tick affected ear, arrows indicate attachment of tick on the ear

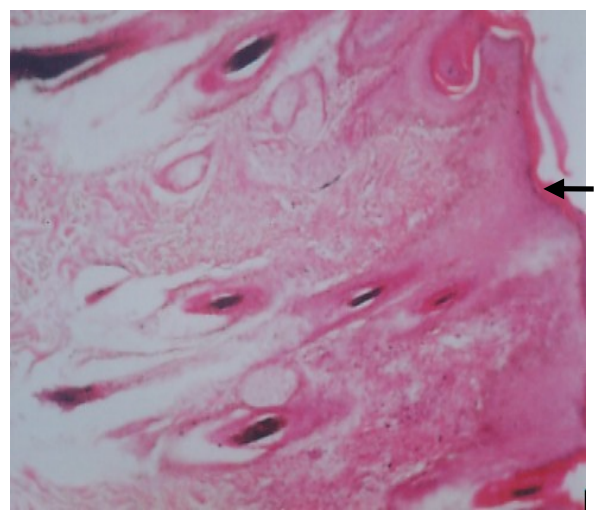

Figure 11. Psoroptes cuniculi infestation in the goat characterized by acanthosis and infiltration of inflammatory cells (330x)

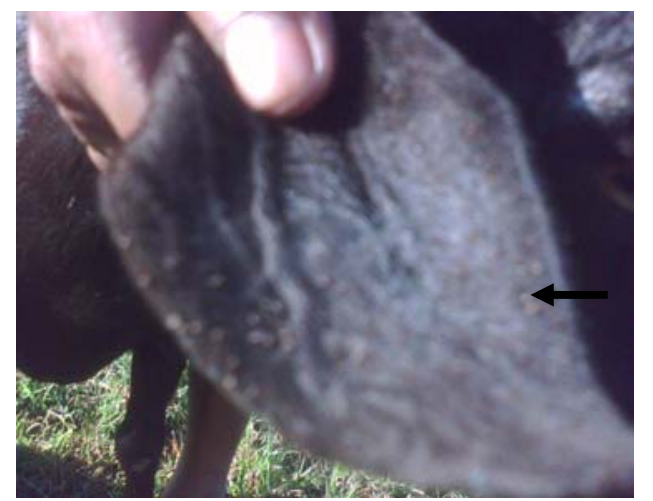

Figure 10. Heavy infestation of ticks on the ear

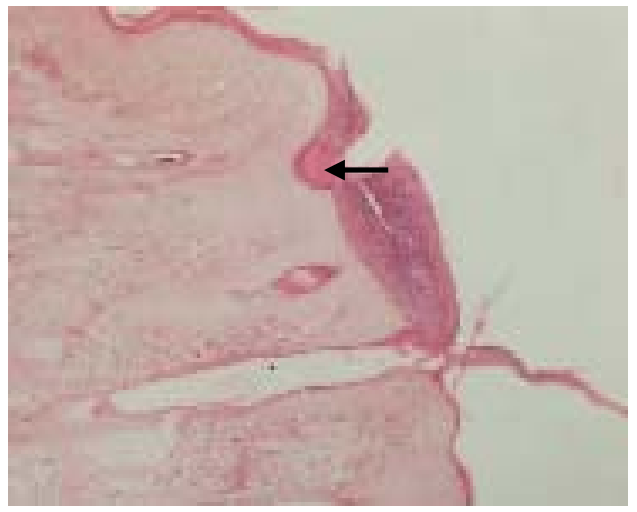

Figure 12. Aggregation of necrotic cellular debris in Psoroptes cuniculi infestation in the goat (330x) 


\section{Sarkar and other}

\section{DISCUSSION}

\section{Epidemiological factors affecting the prevalence of ectoparasites in goats}

The result of the research work indicates that the Black Bengal goats are very susceptible to ectoparasitic infestation. About $72.8 \%$ Black Bengal goats were found to be infested with ectoparasites, of them prevalence of H. bispinosa (34.4\%), B. microplus (27.2\%), D. caprae (20.8\%), L. stenopsis (18.4\%), R. sanguineus (7.2\%) and P. cuniculi (5.6\%) was recorded. Kamal et al. (1996) reported that $44.4 \%$ goats were infested with ticks in the hilly area of Chittagong. Rahman and Mondal (1985) recorded H. bispinosa (74\%) and B. microplus (1.7\%) in goats in Bangladesh. Huq and Mollah (1972) detected $36.2 \%$ goats infested with $D$. caprae and $L$. africans. Kader and Huq (1973) found that $76.3 \%$ goats were infested with $H$. bispinosa and B. microplus in Bangladesh. Parija et al. (1995) observed that 2.22\% goats were infested with Psoroptes sp. in India. Dalapati and Bhowmik (1995) reported 16.3\% infestation with P. cuniculi in goats. Kumer et al. (1994) recorded $38 \%$ L. africans infestation in goats in India. Chakrabarti (1994) observed $13.4 \%$ Psoroptes sp. infestation in goats in India. Pratap et al. (1991) found L. stenopsis (68\%), B. microplus (60\%) and R. haemaphysaloides (52\%) in goats in India. The differences among the results of present and earlier studies might be due to variation in the geographical locations, climatic conditions of the experimental area, methods of study and breed of goats.

During the study, it was revealed that age of the goats had a significant $(\mathrm{P}<0.05)$ effect on ectoparasitic infestation. Kids (82\%) and older animals (79.55\%) were more susceptible to ectoparasitic infestation. The prevalence of Psoroptes sp. was higher in young goats in India (Chakrabarti, 1994). L. africans infestation was the highest on the kids during the first few months of their lives (Horak et al., 2001). It is very difficult to explain exactly the frequent occurrence of ectoparasitic infestation in kids and older animals. But it may be assumed that the less developed immune system of the kids and exhausted immune system of the older animals may be responsible for the higher prevalence of ectoparasitic infestation in kids and older goats.

The prevalence of ectoparasites was higher in females $(77.63 \%)$ than in males $(65.31 \%)$. The prevalence of mange infestation was reported higher in females (29.4\%) in India (Chakrabarti, 1994). The prevalence of $L$. africans in female and male goats and the ratio of female to male was 23:5 in Brazil (Santos et al., 2006). Although the exact cause of higher prevalence of ectoparasitic infestation in female goats can not be explained but it can be assumed that some hormonal influences may be associated with this phenomenon. In fact, higher level of prolactin and progesterone hormones could make the females more susceptible to any infection (LIoyd, 1983). Moreover, stress of production, such as, pregnancy and lactation could have made the female animals more susceptible to infection.

Seasonal fluctuation of the year had a significant $(\mathrm{P}<0.01)$ effect on the prevalence of ectoparasitic infestation in Black Bengal goats. A relatively higher infestation with ectoparasites was observed in rainy season ( $90 \%)$, followed by winter $(82.61 \%)$ and summer $(53.06 \%)$. Similarly, overall prevalence of ectoparasites was higher in rainy season in Brazil (Brito et al., 2005) and tick infestation was abundant in rainy season in India (Latha et al., 2004) and Botswana (Mushi et al., 1996). In contrast, mite infestation was higher in winter season in goats of India (Parija et al., 1995; Chakrabarti, 1994; Mittal and Mathur, 1998). Overall prevalence of acariasis of goat was reported higher in winter in India (Dalapati and Bhowmik, 1995). The contrast between the present and earlier findings can be explained by the fact of variations in the geographical location of the experimental area, topography and composition of soil type, temperature and humidity. Moreover, in this study, a year was divided into three seasons. But in the other parts of the world, there are four seasons in a year. So, this difference in the division of seasons could have made some overlapping of months and seasons and could have created some contradiction. However, the highest prevalence in rainy season may be due to high humidity, heavy rainfall and keeping the goats in close contact which increase the possibility of contamination.

The ectoparasitic infestation was significantly $(\mathrm{p}<0.05)$ higher in Mymensingh $(87.5 \%)$, than that of Gaibandha (57.38\%). This result could not be compared and contrasted due to lack of relevant literature. However, some geo-climatic condition may be associated with this variation. 
Epidemiology and pathology of ectoparasitic infestations in Black Bengal goats

\section{Pathology produced by external parasites}

P. cuniculi

Grossly the $P$. cuniculi infestation was characterized by rough, dry and leathery skin with loss of hair (alopecia). Pathological changes in mite infestation in goats were also described by some other scientists. Dunn (1982a) found psoroptic mange in the ear and the lesions were extended to the poll and to the legs. Wall and Shearer (1997) stated that $P$. cuniculi can cause ear mange in severe infestation and they can block the auditory canal with debris. It also caused irritation, head shaking and scratching as a result the lesions were produced.

Histopathologically the lesions were characterized by hyperkeratosis, acanthosis, eosinophilic infiltration and loss of cornified layer. The lesions caused by P. cunuculi may be due to the penetration of epidermis by the parasites resulting local inflammation and exudation of serum.

\section{Ticks and lice}

Grossly, the skin was rough, reddened, slightly elevated. There were loss of hair and damage due to rubbing. Similar finding was observed by Wall and Shearer (1997). They found dermatitis, intense irritation, pruritis, and alopecia. Ticks and lice bite animals, suck blood and cause mechanical irritation (Soulsby, 1982).

Ectoparasites are prevalent in Bangladesh and factors like season, age and sex have substantial influence on the prevalence of ectoparasites in goat. Since ectoparasite infestation is associated with production loss, pathological lesions and destruction of valuable skin, further detailed epidemiological investigation is needed to prevent and control the ectoparasites in goats.

\section{REFERENCES}

1. Anon. (1986). Statistical Pocketbook of Bangladesh, Statistics Division, Ministry of Planning, Government of the Peoples' Republic of Bangladesh, Dhaka, 258 pp.

2. Brito DRB, Santos ACG, Guerra RMSNC (2005). Ectoparasites in goat and sheep herds from the Alto Mearim and Grajau microregion, State of Maranhao. Revista Brasileira de Parasitologia Veterinaria, 14: 59-63.

3. Cable RM (1957). An Illustrated Laboratory Manual of Parasitology. $4^{\text {th }}$ edn., Burgess publishing Co., Minneapolis, Minnesota, U.S.A.,. 127-128 pp.

4. Chakrabarti A (1994). Incidence of mange in goats in Tripura. Cheiron 23: 122-126.

5. Dalapati MR, Bhowmik MK (1995). An epizootiological study on cutaneous acariasis of goats in West Bengal. Ind. J. Ani. Heal., 34: 1-5.

6. Dunn P (1982). The Goat Keeper's Veterinary Book. $1^{\text {st }}$ edn., Farming Press Limited, Wharfedale Road, Ipswtch, Suffolk, $171 \mathrm{pp}$.

7. Ferris GF (1951). The Sucking Lice. Vol. I., New York Lithographing Corporation, New York, 3 - 285 pp.

8. Hendrix CN, Robinson E (2006). Diagnostic Parasitology for Veterinary Technicians. $6^{\text {th }}$ edn., Mosby Inc, Elsevier. 252253 pp.

9. Hoogstraal H (1956). African Ixodoidea. Vol. I, Department of the Navy, Bureau of Medicine and Surgery, U.S. Naval Medical Research Unit, No. 3, Cairo, Egypt, 50-360 pp.

10. Horak IG, Macivor KM, Greeff CJ (2001). Parasites of domestic and wild animals in South Africa. Helminth and arthropod parasites of Angora goats in the southern Karoo. Onderstepoort J. Vet. Res. 68: 27-35.

11. Huq MM, Mollah MA (1972). A survey of the prevalence of lice on sheep and goats of Dhaka and Mymensingh districts, Bangladesh. Bang. Vet. J. 6: 21-25.

12. Kader SA, Huq MM (1973). A survey on the prevalence of ticks of sheep and goats in Comilla Kotwali Police Station, Bangladesh. M. Sc. (Vet, Sci.) Thesis, Bangladesh Agricultural University, Mymensingh, 27-52 pp.

13. Kumar A, Rawat BS, Saxena AK, Agarwal GP (1994). Prevalence of ectoparasites on goats in Dehradun (India). Appl. Parasitol. 35: 227-236.

14. Latha BR, Aiyasami SS, Pattabiraman G, Sivaraman T, Rajavelu G (2004). Seasonal activity of ticks on small ruminants in Tamil Nadu State, India. Trop. Anim. Heal. Prod. 36: 123-133.

15. Lloyd S (1983). Effect of pregnancy and lactation up on infection. Vet. Immunol. Immunopath. 4: 153-176.

16. Mittal JP, Mathur BK (1988). Effect of house climate on incidence of goat mange in desert region. Rapport, Institutionen for Husdjurshygien, Veterinarmedicinska Fakulteten, Sveriges Lantbruksuniversitet 1: 167-171.

17. Mushi EZ, Isa JFW, Sakia RM (1996). Monthly fluctuation of ixodid tick infestation on indigenous goats in Botswana. Small Rum. Res. 21: 277-279.

18. Mushi EZ, Isa JFW, Seabokeng IB, Kapaata RW (1996). The seasonal fluctuation of ixodid ticks on indigenous Tswana goats in Botswana. Zimb. Vet. J. 27: 41-49.

19. Nooruddin M, Dey AS (1989). Further study on the prevalence of skin diseases in domestic ruminants in Bangladesh. Bang. Vet. 7: 75-81. 


\section{Sarkar and other}

20. Nooruddin M, Mondal MMH (1996). Otoacariasis in Bengal goats of Bangladesh. Small Rum. Res. 19: 87-90.

21. Parija BG, Misra SC, Sahoo PK (1995). Changing pattern in the epidemiology of caprine mange in Bhubaneswar. Ind. Vet. J. 72: 536-538

22. Pratap G, Misra SC, Panda MR (1991). A note of the incidence of ectoparasites on Black Bengal goats at Bhubaneswar. Ind. Vet. J. 68: 92-94.

23. Rahman MH, Mondal MMH (1985). Tick fauna of Bangladesh. Ind. J. Parasitol. 9: 145-149.

24. Roberts FHS (1952). Insects Affecting Livestock. $1^{\text {st }}$ edn, Angus and Robertson Ltd., London, 17-191 pp.

25. Santos SBD, Cancado PH, Piranda EM, Faccini JL (2006). Infestation with Linognathus africanus (Linognathidae) and Bovicola caprae (Trichodectidae) in goat flock of the State of Rio de Janeiro, Brazil, Review of Brazilian Veterinary Parasitology 15 (1): 41-43.

26. Schesselman JJ (1982). Case-Control Studies, Oxford University Press, New York, 174-177 pp.

27. Soulsby EJI (1982). Helminths, Arthropod and Protozoa of Domesticated Animals, $7^{\text {th }}$ edn, Bailliere Tindal, London. $136-778 \mathrm{pp}$.

28. Wall R, Shearer D (1997). Veterinary Entomology. $1^{\text {st }}$ edn., Published by Chapman and Hall, London, 43-135. P 